\title{
Imagens que advem. Por uma antropologia da imagem fotográfica em A câmara clara
}

\author{
RODRIGO FONTANARI
}

\section{Resumo}

Há mais de trinta anos da publicação francesa de $A$ câmara clara, esse artigo busca fazer uma incursão a essa considerada derradeira obra em vida de Roland Barthes, um dos mais importantes pensadores do século XX, a partir das notas preparatórias para a escrita desse livro, consultadas no "Grand Fichier" de Barthes depositado atualmente na Bibliothèque Nacional de France (BNF), notadamente, da "pochette" intitulada "Photo". Destas notas, percebe-se que Barthes, para além do semiólogo que foi, também se revela um antropólogo das imagens que procura por outro olhar para o mundo das imagens, que as tira da condição de simples superfície de superficialidades.

Palavras-chave: Imagem, fotografia, Roland Barthes 


\section{Images that come. For an anthropology of the photographic image in The camera lucida}

RODRIGO FONTANARI

Abstract

The more than thirty years since the French publication of The camera lucida, this article seeks to make a foray considered this last work in the Roland Barthes'life, one of the most important thinkers of the twentieth century, from the preparatory notes for writing this book, found at "Grand Fichier" Barthes currently deposited in the Bibliothèque National de France (BNF), notably the "pochette" entitled "Photo". These notes, its clear that Barthes, in addition to the semiotician who was also proves to be an anthropologist of the images you are looking for another look at the world of images that draw from the status of mere surface superficialities. 


\section{As imagens ganham Roland Barthes}

Há um pouco mais de trinta anos de distância da publicação francesa de A câmara clara, o que temos ainda a dizer dessa peça em prosa, que, por sua estranha força, parece ser uma das mais radicais e, por isso mesmo, intrigantes, reflexão a respeito da fotografia, notadamente, da filosofia da imagem contemporânea?

Trata-se, aqui, de fazer portanto uma incursão rumo a uma face do legado barthesiano que seus críticos estão ainda em dívida. Embora grande parte de sua trajetória ensaística sobre imagem, seja ela de que suporte for, é marcada por um esforço do autor em entender os signos não verbais como um sistema linguístico, aliás, como fizeram todos os pensadores de sua escola (o Estruturalismo), presos ao paradigma saussuriano da língua versus fala.

Roland Barthes soube logo perceber certos aspectos puramente imagéticos, que insistem, aderem, sobrevivem na imagem, advem ao espectador e são irredutíveis a uma significação (mensagem) ou por ela possa ser reduzidos. É esse mesmo movimento que se pode perceber em sua incursão ao mundo da fotografia, notadamente, do retrato fotográfico e do álbum de família, que, culminará, em 1980, com a publicação de $A$ câmara clara.

Uma leitura atenta de $A$ câmara clara permite-nos afirmar que Barthes foi, sem dúvida, um dos poucos teóricos franceses que soube recepcionar as imagens, livrando-as da iconoclastia novecentista da "denúncia piedosa", detratada por uma tradição bem estabelecida de ataque aos simulacros como se se tratasse de uma espécie de "cruzada"². Barthes apressa-se, portanto, em colocar certas fotografias para além da simples 
ideia de signo, prefere tomá-las como vivências, supervivências, ou ainda, como formas anacrônicas, que pertencem a um tempo muito profundo - quiçá imemorável -, capazes de nos levar a outras profundezas.

Portanto, a questão do olhar em A câmara clara, merece algumas considerações. Sabe-se que todo signo só existe e se atualiza no olho do outro. É preciso um olhar capturado para dar sentido ao universo sígnico. E olhar é antes de tudo interpretar. Resulta de uma elaboração cognitiva que busca compreender, traduzir uma forma de pensamento em outra. Uma imagem representa um objeto que está fora dele e se apresenta à mente do espectador em que se processará um outro signo ou pensamento em que seu sentido se traduz. Há uma espécie de crosta sígnica que nos possibilita fazer a mediação com o mundo, mas também, é ela a responsável por nos retirar de um contato direto, palpável, sensual com esse mundo sensível que nos envolve. Entretanto, a questão do olhar, em A câmara clara, parece ser mais complexa e parece suscitar esse olhar a ir ver as imagens alhures. Fora da condição de simples superfície de imagética.

Nem iconoclasta, nem semioclasta, o Barthes de A câmara clara torna-se um antropólogo das imagens. Progressivamente, as investigações heurísticas de Barthes em torno da imagens conduziu-o a um questionamento muito mais radical do que o esteticismo vago encampado pelos sociólogos bem como da "curiosidade gulosa" dos semiólogos. Um saber das imagens mais violento, mais visceral que se estabelece entre o espectador e a própria imagem. Pois logo Barthes entrevê que a imago é, ao mesmo tempo, tanto uma questão de aparição visual (ressoa) quanto de experiência corporal.

Com isso, o semiólogo das imagens, passa a poeta das imagens pungentes e, consciente ou inconscientemente, se inscreve dentro de uma tradição iconológica e da antropologia cultural que entrevê as imagens como uma sobrevivência ou supervivência e que são capazes de atravessar o tempo e se nutrirem de histórias e de memórias que as precedem, como ausências ressurgentes.

Trata-se, portanto, de uma relação exegética com o visual. Ver para além do visível. Etimologicamente, a exegese consiste no movimento de "ir além" ["au-delà"] ou para além dos limites do sentido evidente, mundo do visível, e adentrar aquele do visual, em que as imagens são presença sem imitação ou ainda mais expressivamente, onde a semelhança cede passagem à presença. A exegese, ao contrário daquela leitura que encerra os sentidos nos limites do significado, busca abrir 
o texto - no caso, a imagem -, a todas as possibilidades de sentido nele latente. E nessa "abertura”, a "verdade" não seria alcançada numa relação direta, mas com elementos do enigma. Esse deslocamento implica numa perda de significação e de história, em detrimento de um ganho em mistério e significância3 . O espectador, aquele que olha se funde e se confunde com a profundeza daquele que é olhado, envolvendo-se na trama da imagem.

Merleau-Ponty em $O$ visível e o invisível, lembra que o olhar fenomenológico "envolve, apalpa, esposa as coisas visíveis”. Numa interação do visível e do tangível. O visível é a qualidade de uma textura, a superfície de uma profundidade. É isso que o próprio Merleau-Ponty nomeia de "a carne do visível”. As coisas não são achatadas, de duas dimensões, mas seres dotados de profundidade, só acessíveis àquele que com elas coexiste num mesmo mundo, isto é, deve haver um parentesco entre o olhar do outro e o meu corpo vivo, que remete a "um único mundo" em que o sujeito "que olha não seja, ele próprio estranho ao mundo que olha" (MERLEAU-PONTY, 2007, p. 132). Um mundo de imbricações, afinidades, entrelaçamento, intercorporalidade ou ainda, de reversibilidade. A visibilidade constitui-se dessa "espessura da carne" de que fala Merleau-Ponty, que se estabelece entre o vidente e a coisa. Nas palavras do próprio autor:

O corpo nos une diretamente às coisas por sua própria ontogênese, soldando um a outro os dois esboços de que é feito, seus dois lábios: a massa sensível que ele é e a massa do sensível de onde nasce por segregação, e à qual, como vidente, permanece aberto. E ele é unicamente ele, por que e um ser em duas dimensões, que nos pode levar às próprias coisas, que são seres planos mas seres em profundidade, inacessíveis a um sujeito que os sobrevoe, só abertas, se possível, para aquele que com elas coexiste no mesmo mundo. Ao falarmos de carne do visível [....] O que chamamos de visível é, dizíamos, uma qualidade prenhe de uma textura, a superfície de uma profundidade, corte de um ser maciço, grão ou corpúsculo levado por uma onda do Ser (2007, p. 132-133).

É a partir da indagação da essência - do noema - da fotografia, ou mesmo, daquilo que a difere dos outros tipos de imagem, da pintura, do cinema, que deveríamos examinar essas fotos. Tomando muito seriamente, as reflexões barthesianas a respeito da fotografia, deparamo-nos com o fragmento 35, 
no qual relata a razão pela qual a fotografia sempre lhe espantava. Seu espanto nascia do aspecto químico da imagem, pois, embora a arte fotográfica seja devedora da câmera escura dos pintores, foi a descoberta da sensibilidade à luz dos sais de prata, pela química que possibilitou o registro e a fixação da imagem. Insistindo bastante no aspecto químico da imagem, Barthes atribui à foto um caráter mágico, uma imagem não produzida pela mão do homem acheiropoietos. Então, declara Barthes, "A fotografia espanta-me sempre, como um espanto que perdura e se renova inesgotavelmente. Talvez esse espanto, essa teimosia, mergulhe na substância religiosa a que estou afeiçoado"4 (OC, V, p. 855).

Tal é o fascínio perturbador que esse tipo de imagem desperta em Roland Barthes que, algumas linhas adiante, nota ainda o autor: "A fotografia tem algo a ver com a ressureição: não se poderá dizer dela o que diziam os Bizantinos da imagem de Cristo de que está impregnado do Sudário de Turim [...]" (OC, V, p. 855).

\section{Chamuscamento do real}

A fotografia de certo modo, espantosamente, parece ressuscitar o sujeito representado na medida em que a imagem revelada pela emulsão química não nos impõe outra reflexão se não sobre o tempo, pois ela nos diz que algo que aconteceu assim, tal qual está dado aos nossos olhos. Pura contingência ou confluência de tempo e espaço: foi preciso que o fotógrafo estivesse lá, naquele exato momento, e que voltasse o olho da câmera para aquela cena, e que, disparasse o clique naquele exato momento em que a cena acontecia. Eis aí o noema da fotografia, a confluência "isso aconteu" ["ça a été"] e "ter estado aqui" ["avoir été là"]. A fotografia na concepção de Barthes pode ser entendida como uma chamuscada [tuché] do real sob o filme fotográfico. Ela é o encontro do passado e do presente, ou melhor, de um eterno presente que diz algo do passado. Ora, isso em nada equivale, do ponto de vista de Barthes, à memória, ou até mesmo à memória involuntária proustiana, aliás, bastante confundida quando se trata de pensar o tempo na fotográfia a partir da leitura de A câmara clara. A imagem fotográfica, insiste Barthes, não rememora nada, ela simplesmente, coloca diante dos nossos olhos, num eterno presente, um acontecimento do passado. Tanto é que ele mesmo nota que o tempo da fotografia é aorista ${ }^{5}$, ou seja, um tempo passado indefinido ou indeterminado. Há portanto, na fotografia 
duas noções de tempo que correm paralelas e concomitantemente: de um lado, um tempo que é aquele do ato fotográfico que, para que a foto exista - ou mesmo para que a foto seja feita - é necessário que aquilo que está representado tenha acontecido. E de outro, o tempo do registro, da impressão,ou seja, simplesmente o tempo que se imprime sobre a imagem em si mesma, aquela que se revela diante dos nossos olhos, e que nos coloca num tempo sempre presente: aquilo é vivo, enquanto registro de algo ou alguém o que não se pode mudar, aquilo que foi registrado, ou enquanto os sais impregnados do sujeito fotografado existirem. Dessa confluência não se pode dizer outra coisa do que aquilo que Barthes mesmo já disse: "de cada retrato salta a figura de um morto" (OC, V, p. 876). Morto enquanto representação de um sujeito que está morto e ao mesmo tempo, a morte iminente, na medida que aquele que foi capturado naquele instante, no minuto anterior, já não existe mais, e, se algo ainda existe daquele mesmo sujeito - foto, talvez - pelo desgaste do tempo anuncia a própria morte (apagamento). Fato esse que faz com que Barthes escreva em relação às fotos que ele observa, "ele vai morrrer", "ele está morto" (OC, V, p. 866).

Se para que a imagem fotográfica seja produzida é necessário que haja a presença de um referente e, ainda se tomarmos a palavra fotográfica a partir do que nos mostra sua própria raiz etimológica grega, fótons (luz) e graphie (escrita, inscrição), grafia da luz: a ação de "inscrição" da luz sobre certas superfícies sensíveis (superfície de sais de prata) - a imagem disso resultante torna-se, de algum modo, uma espécie de imagem relíquia pois, afinal, essa imagem se forma a partir de algo que emanou do sujeito fotografado e ali permaneceu para sempre, eternizado, ou mesmo, fixado ou congelado para sempre, na emulsão dos sais de prata.

Acreditamos que muito mais do que uma reflexão semiótica da fotografia, o texto de $A$ câmara clara é uma leitura particular, que tende a questões filosóficas e antropológicas da imagem fotográfica. Embora o silêncio de Barthes ao não mencionar em suas referência o conhecido ensaio de André Bazin "Ontologia da imagem fotográfica", parece-nos ser desse texto que Barthes retira algumas das considerações a respeito da fotografia que encontramos em A câmara clara. Simplesmente a título de informação, André Bazin foi um dos fundadores e diretores da revista Cahiers du cinéma à pedido da qual, Roland Barthes, acabou por redigir a sua derradeira obra em vida. Demoremos um pouco sobre esse texto. 
Esse ensaio originalmente publicado em 1958, se encontra no volume Qu'est-ce que c'est le cinéma?, já traduzido em português pela editora Brasiliense para coleção "Primeiros Passos". Ontologia da imagem fotográfica, escrito a partir de uma perspectiva realista da imagem fotográfica, pode ser considerado um texto que funde a imagem fotográfica como um meio que registra algo mecanicamente sem a intervenção direta do ser humano. Analisando de perto esse sistema de produção e reprodução de imagens técnicas, Bazin coloca em cena um fator psicológico: a crença do sujeito (espectador) na fidelidade da reprodução fotográfica. Nas palavras do autor:

A originalidade da fotografia em relação a pintura reside então na sua objetividade essencial. (...) Pela primeira vez, entre o objeto inicial e a sua representação, nada se interpõe, a não ser um outro objeto. Pela primeira vez, uma imagem do mundo exterior se forma automaticamente sem a intervenção criadora do homem segundo um determinismo rigoroso (BAZIN, 1991, p. 22).

Revisando os registros históricos sobre a civilização egípcia e sua cultura de retardar ou impedir o desaparecimento do corpo dos faraós e dos nobres, por meio de seu embalsamamento, Bazin vê nesse ato de "fixar artificialmente as aparências carnais do ser é salvá-lo da correnteza da duração" (1991, p. 19), o fundamento psicanalítico das artes plásticas, pois, na origem da pintura, da escultura, por que não incluir aí, a fotografia, se encontra, escreve o autor, "complexo da múmia" (1991, p. 19). Acontece que com a evolução em paralelo das artes e da civilização, o caráter mágico foi abrandado, pela sublimação da necessidade e exorcizar o tempo. "Não se acredita mais na identidade ontológica do modelo e do retrato, nota Bazin, porém se admite que este nos ajudar a recordar aqueles e, portanto, ajuda a salvá-los de uma segunda morte espiritual" (1991, p. 20).

Analisando de perto a questão da imagem fotográfica, nota Bazin que o que há de mais profundo nesse tipo de imagem não está no seu resultado, mas em sua na gênese: a fotografia se assemelha aos processos mais rudimentares da modelagem das máscaras mortuárias, uma espécie de traço, vestígio (empreinte, em francês) de corpo ou de algo que se pôs diante da objetiva. Diante de uma foto somos obrigados a acreditar na existência do objeto representado na medida em que, representar (re-presentar) é tornar presente algo no tempo e no espaço. Nesse tipo de imagem, a reprodução expressa 
a mesma realidade que objeto em si. Essa imagem torna-se uma verdadeira relíquia devido ao realismo, tal como, deparamo-nos no santo sudário do qual emerge a síntese perfeita entre a relíquia e a fotografia.

Partilhando do mesmo olhar de Bazin, Barthes também incita, não sem razão, a uma leitura da fotografia, não como um signo, pois "não é a imagem que eu vejo, é o referente", nota Barthes (OC, V, p. 794). Assim, para falarmos em termos semióticos, a fotografia na concepção barthesiana está evidentemente relacionada ao conceito pierciano de índice. Ora, não há nenhum problema de ordem epistemológica em aproximar o universo binário do signo do qual sai Roland Barthes, do universo triádico de Pierce, afinal, no limite, em ambas as semióticas são debatidas a relação entre as palavras e as coisas. Do mais, com já sabemos desde a publicação do manual dos semioticistas franceses, Elementos de Semiologia, em 1964, que, de alguma forma, Barthes já apresentava conhecimento das classificações sígnica de Pierce ao citá-lo, ao menos em sua tabela de leitura e classificação dos signos que está dada nesse livro ( OC, II, p. 656).

Para Pierce, o índice é algo que mantem uma conexão com o objeto concreto representado, tanto isso é válido para a fotografia que é por natureza um registro, uma marca, um traço de um referente cuja luz emanada do corpo produziu o tal resultado sobre a chapa metálica: "Diríamos que a Fotografia traz consigo o seu referentes - nota poeticamente ainda Barthes que -, ambos atingidos pela mesma imobilidade amorosa ou fúnebre, [...] [estão] colados um ao outro, membro a membro" (OC, V, p. 793). De resto, é o próprio Pierce que autoriza essa compreensão, quando define em poucas linhas seu conceito de índice: "um índice ou sema (grego) é um representamen cujo caráter representativo consiste em um segundo indivíduo. Se a secundidade é uma relação existencial, o índice é autêntico" (1978, p. 158). Se há uma conexão real com o objeto, a concepção indiciária do signo aí está.

O regime de representação estabelecido pela fotografia instaura no seio das imagens, uma indução que nenhuma outra seria capaz de poder despertar: autenticidade e veracidade. Não obstante, admite Barthes que diante da fotografia, "eu confundira verdade e realidade numa única emoção” (OC, V, p. 851).

Se a incursão de Barthes pela invenção da fotografia se fez privilegiando a descoberta química em detrimento da física, é porque a fotografia de fato, se revela a partir dimensão da imanência. As implicações químicas do tempo, na fotografia, 
voltarão, brutalmente, às reflexões barthesianas. Um marco desse momento é a descoberta, numa noite de novembro, da foto Jardim de Inverno, na qual se encontram sua mãe, com cinco anos, ao lado do irmão dela, com sete anos, no jardim de inverno da casa em Chennevièrres-sur-Marne, na qual ela havia nascido. Nos textos, Mensagem Fotográfica e Retórica da Imagem, do período mais semiológico de Barthes - se assim podemos dizer -, a questão do "ter-estado-aqui" implica a aderência do referente à imagem, o que lhe atribui um caráter mágico que é modestamente sufocado pela ideia de uma realidade da qual estamos excluídos, (isso aconteceu, mas sem nós), "uma realidade da qual estamos protegidos", nota Barthes. Em A câmara clara, esse "ter-estado-aqui" não é mais vivenciado simplesmente como aquele momento raro de registro que assinala a copresença do fotógrafo e do acontecimento, mas se fundamenta sobre o aspecto químico que irrompe como a essência da elaboração da imagem.

\section{Foto: um relicário}

Esse ponto de vista adotado não nos parece nem um pouco absurdo, visto que a química perpassa todo o percurso de construção da imagem fotográfica. E seguir o desenvolvimento do pensamento de Barthes do ponto de vista químico da imagem "é assistir - observa Jacqueline Guittard - ao nascimento do fantasma radioso da mãe desaparecida" (2004, p. 237), o que acaba por atribuir a esta imagem um aspecto de relicário: uma relíquia que guarda e emana, sobre quem a olha, radiações luminosas daquele sujeito que amamos e que, um dia, se pôs ali diante da objetiva e se fez fotografar. Não diríamos que essa imagem seja realmente um fantasma por se tratar de emanação de um referente de algo que realmente existiu; a foto é a sobrevivência, de algum modo, da energia daquele ser que esteve aqui [avoir été là] diante da objetiva: imagem congelada sob a forma de traço luminoso na chapa sensível de sais de prata. Assim, ao se debruçar sobre a etimologia da palavra película [pellícule], a qual se utiliza seja para nomear o filme fotográfico ou o cinematográfico, descobre-se a sua verdadeira raiz, a de ser, no sentido amplo do termo, uma pequena pele, uma fina membrana, o que leva Barthes a escrever, nos primeiros rascunhos de $A$ câmara clara, "[...] verdade da etimologia: a película é uma pele e com a fotografia, eu trabalho à flor da pele" (sd., f. 6).

Pensar a fotografia como esse pouco de alguma coisa - de 
pele, de emanações luminosas do sujeito fotografado - não nos parece tão irracional, visto que, de algum modo, essa visão cumpre uma concepção mágica do processo de registro e de revelação. Tal processo é próprio da fascinação exercida por essa representação, desde as origens do dispositivo fotográfico, que a vinculam a uma carga de emoções irracionais de que se desprendem essas "imagens que registra o aparelho - escreve Daniel Grojnowisk, em Usage de la photographie - são permeáveis [perméables] às miragens" (2011, p. 180).

De resto, é o próprio trabalho da história desse "media" que o coloca, particularmente, de par como o Espiritismo e todo trabalho de mediunidade, pois a fotografia encurta e também transpõe, sobre o plano da técnica, concepções e procedimentos que são peculiares e a aproxima da ciências ocultas. Toda essa aproximação não parece estranha, pois, também não sem razão, aquele vulto, a imagem latente, que é da ordem de uma impressão indiscernível que a câmara escura registra sobre o negativo, e que por sua vez, o trabalho de revelação do laboratório fotográfico torna visível, se assemelha ao "perespírito" que segundo o Espiritismo é uma espécie de estado intermediário entre o corpo e o espírito, que está tanto apto a se materializar, quanto a se desmaterializar, em outras palvras, é tanto latente, quanto manifesto.

Ora, tudo isso parece também valer para o universo da fotografia, pois podemos interpretar a placa sensível sobre a qual a imagem latente se imprime como uma espécie de "media" químico cujo poder de visualização ultrapassa aquele do olho humano. Esse olhar fotográfico, que coloca en abyme o media mecânico em detrimento de uma percepção suprassensível que desperta o medium químico, acaba por transformar o "médium" fotográfico em algo "mediúnico" pois, como sentencia Pedro Miguel Frade, a fotografia traz "quimicamente o tempo a um êxtase" (1992, p. 207).

Desta feita, a imagem fotográfica se torna capaz de transpor o plano da técnica e se aproxima do plano suprassensível, que interessa às ciências ocultas. Referimo-nos, propriamente tanto ao processo que ocorre na câmara escura, na formação da imagem latente que se imprime sobre o negativo e que o processo de revelação torna visível, quanto à placa sensível, o "media" químico da imagem que, pela sua fóton-sensibilidade, captura para além do olho humano. Isso torna a imagem fotográfica uma relíquia compreendida como um objeto qualquer que, enquanto estiver restrito ao seu cotidiano, não terá qualquer valor sacro, mas que, se por alguma razão, lhe atri- 
buem ou lhe investem de um valor sagrado, esse objeto passa a ocupar um lugar na medida especial, pois apresenta-se, ao mesmo tempo, como um objeto qualquer e como um objeto investido de sacralidade, que se torna uma espécie de suporte, outro corpo que é concedido àquele que partiu. No limite, dá ao morto, a possibilidade de uma nova existência, negando a sua morte. É essa dupla existência da relíquia - um objeto banal e um objeto sagrado - que se torna uma garantia contra a morte. A transformação da foto em relíquia, ao nosso ver, é também - como nota Bernard Comment em Roland Barthes, vers le neutre - resultado da operação de um deslocamento que faz a fotografia passar da ideia "sinédoque ou a metonímia (de ordem espacial: um fragmento para tudo perdido)" para aquela da "hipotipose (de ordem temporal: passado e presente confundidos)" (2002, p. 128).

De outra maneira, a relíquia, no sentido eclesiástico do termo, é aquilo que resta do corpo, ou mesmo, aquilo que tenha de alguma forma, tocado um corpo santificado que fecundou aquilo que era um simples objeto profano (a fotografia). Uma centelha, um grão de presença que atribui ao objeto, no qual ela faz morada, um pouco de melancolia e de nostalgia. Então Barthes em A câmara clara, percebe que há na fotografia - escreve Bernard Comment - uma

Dupla morte e ressurreição, verdade presente e realidade passada, instante e perdurância [perdurance], fusão e separação: a escritura da fotografia realiza a antilogia e esse Romance, que um acaso infeliz fez sinal, é realmente a da heterologia, talvez: o Neutro. Assim, ela afeta uma certa irracionalidade (2002, p. 128-129).

Essa relação da foto com a relíquia não nos parece estranha, ao menos se a tomarmos como inscrição da morte e do morto na imagem fotográfica, algo que também já é notado e sugerido por Henri Van Lier, em Philosophie de la photographie,

Como impressão luminosa, a foto é a presença íntima de algo de uma pessoa, de um lugar, de um objeto. Ao mesmo tempo, dá uma caução mais forte do uma-vez-nunca-mais. Data impiedosamente os seres que são para nós os mais vivos, mas fora de qualquer duração. Ela os coloca num espaço estritamente localizável, mas fora dos verdadeiros lugares. Cada um nela não passa de uma fração de instante de um corte de espaço que não podemos viver nem reviver (...) Vemos o proveito 
que o amor, o ódio, a espera, a desolação e o luto podem tirar da fotografia. Misturados ou no álbum de família. Ou ainda emolduramento é costume. Funciona como relicário, transformando a foto em relíquia, talismã ou amuleto. Em todo caso em mortalha ou túmulo que não precisa de inscrição porque é ela a própria inscrição (1983, p. 53).

Recapitulemos então, todo esse percurso dessa instigante reflexão. Muito antes da descoberta da foto Jardim de Inverno, ainda no âmbito dos primeiros fragmentos de $A$ câmara clara, mais exatamente no fragmento quatro, na busca por saber o que é a fotografia em sua essência, Barthes observa que

Tecnicamente a fotografia está na encruzilhada de dois processos absolutamente distintos: um de ordem química, a ação da luz sobre certas substâncias; outro, de ordem física, a formação da imagem através de um dispositivo óptico (OC, V, p. 795).

Algumas linhas mais abaixo, dentro da perspectiva que havia adotado - falar da fotografia do ponto de vista daquele que olha (Spectator) - Barthes afirma: "Parecia-me que a Fotografia do Spectator descendia essencialmente, se assim se pode dizer, da revelação química do objeto (do qual recebo os raios por retardamento) [...]" (OC, V, p. 795). Nove fragmentos mais adiante, Barthes, colocando-se na posição do primeiro homem que viu a primeira imagem fotográfica, "deve, - escreve o autor - ter pensado que se tratava de uma pintura, o mesmo enquadramento, a mesma perspectiva" (OC, V, p. 811). Porém, como insiste pouco mais adiante Barthes, essa dívida com a pintura é somente técnica em partes, pois a imagem fotográfica não nasce simplesmente do enquadramento e da perspectiva da câmara obscura, é preciso que algo registre, inscreva e fixe a imagem sobre a superfície sensível, e esse algo, nota Barthes "foi a descoberta da química" (OC, V, p. 813).

No fragmento 21, retomando a ideia de que a imagem fotográfica tem pregnância química, nota Barthes, "[...] diz-se 'revelar uma foto' ['desenvolver uma foto'], mas aquilo que a ação química revela [desenvolve] éo 'irrevelável' ['indesenvolvível'], uma essência (de ferida), aquilo que não pode transformar-se, mas apenas se repete sob a forma de insistência (do olhar insistente)" (OC, V, p. 828). Alguns fragmentos adiante - n. 34Barthes escreve que a essência da imagem fotográfica, "ça a été", "[...] só foi possível a partir do dia em que uma 
circunstância científica (a descoberta da sensibilidade à luz dos sais de prata) permitiu captar e imprimir diretamente os raios luminosos emitidos por um objeto diferentemente iluminado" (OC, V, p. 854).

\section{O grão da imagem}

A foto é "literalmente uma emanação do referente" (OC, V, p. 854). É do aspecto químico dessa imagem que emerge a possibilidade de pensar a fotografia não mais simplesmente como um objeto semiológico, mas como um relicário, na medida em que os sais de prata [halogénures d'argent] possibilitaram a fixação e a transmissão dos raios luminosos que partiram de um corpo que, num momento qualquer do passado, posou diante da objetiva. Assim, essa inscrição da luz nos diz ainda que "isso existiu" [ça a été] e perdura ainda [c'est encore là] sob a forma de radiação luminosa dos sais de prata, e essas partículas tornam-se, de alguma maneira, uma membrana química que vem fazer a mediação entre os corpos, para dizer mesmo como Barthes, "uma espécie de ligação umbilical liga o corpo da coisa fotografada ao meu olhar: a luz, embora impalpável, é aqui um meio carnal, uma pele que eu partilho com aquele que foi fotografado" (OC, V, p. 854).

A fotografia, dessa perspectiva química, vem tocar aquele que a observa com a própria luz do corpo daquele que se deixou aprisionar pela objetiva. Ouçamos o próprio Barthes: "De um corpo real, que estava lá, partiram radiações que vem me tocar, a mim, que estou aqui. Pouco importa a duração da transmissão; a foto do ser desaparecido vem me tocar como os raios emitidos por uma estrela" (OC, V, p. 854).

Em La technique et le temps, Bernard Stiegle nota que a luz da fotografia é "um meio carnal" que, no limite, permite, "ainda que com atraso, - escreve o autor - a reversão do instante passado no presente do olhar; sua reversão, isto é, sua passagem" (1996, p. 26). A própria etimologia da palavra "fotografia" revela um pouco do seu ser e isso, para Barthes, não é sem razão, pois é um processo de expressão e mediação da luz; tanto é que, rememorando a palavra em latim, se diz imago lucis opera expressa, isto é, "imagem revelada, "saída", "montada", "espremida" (como um suco de limão) pela ação da luz" (OC, V, p. 854). E a isto, "acrescentaríamos - nota ainda Barthes - a ideia de que esse metal, como todos os metais de Alquimia, está vivo" ${ }^{\text {. O }} \mathrm{O}$ que a fotografia faz com o corpo, não é somente uma imortalização, "pela mediação de um me- 
tal precioso, a prata (monumento e luxo)" (OC, V, p. 854), mas muito mais do que isso, ela é capaz de fazer ressurgir (ressurreição), isto é, de certa forma, por meio dos raios luminosos, que ali estão depositados, a fotografia reaviva e nos coloca, subitamente, diante do sujeito que partiu.

Há, portanto, uma certa granulosidade, grãos de sais de pratas que são tocados (escurecidos) pela luz que parte do objeto posto a sua frente, e esses "pontos negros" da imagem dizem muito da natureza da imagem. É dessa granulosidade fotográfica que, talvez, estivesse falando Joseph Niépce em carta intitulada "Noticie sur quelques résultas obtenus spontanément par l'action de la lumière", endereçada à Royal Society of London, quando escreve, em o8 de dezembro de 1827, que mais do que todas as vantagens e aplicações a que são suscetíveis sua invenção, ele reforçaria um aspecto que poderíamos dizer ser a essência da fotografia. Trata-se, diz o autor, de um objeto "pungente pela fascinação" [piquant par l'attrait] (1983, p. 124). Fascinação que surge dessa possibilidade bizarra de estarmos diante de algo que não é nada mais do que partículas luminosas que partiram de um corpo, tocaram a superfície sensível do filme fotográfico e foram aí aprisionadas e continuam a irradiar luz. A exemplo disso, vejamos então, aquelas imagens que podemos considerar as primeiras imagens fotográficas: Paisagem à Saint Loup de Varenne, 1816, feita por Niépce e aquela outra foto de Auguste Salzmann, Jerusalém e o caminho de Biet-Lehem, 1850 . Nelas podemos perceber nitidamente, a textura rugosa dos grãos de sais de prata escurecidos, dos quais a imagem fotográfica se constitui. Esses pequenos grãos, formando uma imagem, aparecem exemplarmente representados tanto na primeira fotografia de Niépce, em que são bastante evidentes, quanto diante daquela imagem do caminho de Jerusalém, em que temos a sensação perceptível de podermos tocar um dos grãos de areia que traçam caminhos naquela vasta paisagem árida.

Essa apreensão da fotografia pelo viés da química nos faz perceber que o que a imagem fotográfica nos revela, nos dá a ver sobre a superfície do papel, é uma outra categoria de imagem, em que ela deixa de ser cópia da cópia do objeto, para ser nas palavras de Barthes, "Spectrum da Fotografia" (OC, V, p. 795), um verdadeiro "milagre da transubstanciação". Uma imagem archeiropoiético da luz, na medida em que esse conceito permite expressar com rigor a diferença específica da natureza dessa imagem, que se fez a si própria pela luz, sem a intervenção da mão do homem. 
Há nessa imagem, a existência miraculosa da luz, que pode deixar inebriado aquele que a olha. Assim, a foto é de alguma forma, uma imagem viva que encarna, por meio de operações químicas, a energia daquele que ali esteve e faz com que esse sujeito, ainda que na forma espectral, ressurja da luminosidade química que não cessa de se irradiar sobre quem a olha. A fotografia encanta e entristece pelo fato de que ela nos diz, através das "radiações imediatas (a sua luminescência)", que outrora um corpo "tocou realmente a superfície que, por sua vez, o meu olhar vem tocar" (OC, V, p. 854-855).

Se encararmos a fotografia como uma imagem indiciária - como o diz Barthes, com outras palavras, desde as primeiras linhas de A câmara clara - pois, de alguma maneira, um corpo tocou (houve contato), ainda que simplesmente luminoso, uma chapa sensível. E a partir disso, parece-nos que a fotografia se constitui de um duplo plano. Por um lado, esse seria uma espécie de ectoplasma da fotografia, de um índice luminoso, um traço negativo do corpo fotografado que é milagrosamente revertido tal como uma verdadeira ressurreição, que seria então o negativo. Por outro lado, um segundo que é o figurativo, em que a imagem se dá a ver, se torna visível ao olho do outro.

Assim entendida, a fotografia talvez possa ser vista numa estreita relação com o Santo Sudário. Os leitores de Barthes não estranharão tal afirmação, pois sabem, através da biografia de Calvet, do fascínio com que falava Barthes, aos seus amigos, sobre essa relíquia religiosa (Cf. 1993, p. 125).

Esse tecido sobre o qual o corpo de Cristo se teria imprimido diretamente, nota Dubois, "é, no fundo, a primeira -'fotografia' de crime" (2008, p. 223). E acrescenta: "O negativo como fantasma, a revelação como uma Ressurreição" (2008, p. 223). Ocorre ainda que, se a fotografia pode, de algum modo, ser lida à luz dos mitos da origem da imagem cristã, que contempla um arco que vai da encarnação, passando pelo episódio de Verônica, chegando naquela do Santo Sudário, é porque neles está implicado "o vínculo da luz, do sangue e do contato" (2008, p. 150). Diante do Santo Sudário de Turim, encontramos a síntese perfeita entre a relíquia e a fotografia.

Ali, onde os detratores da fotografia veem o resultado de elaborações técnicas do aparelho e de manipulações técnicas do fotógrafo, isto é, uma pura ilusão especular, Barthes, reverte o signo fotográfico, colocando o extra-signo dentro do próprio signo, acenando ainda com a possibilidade de leitura da foto como a inscrição do corpo. Pensar a fotografia como um registro químico, escreve Andre Rouillé em A fotografia, re- 
força "[...] a representação em seu funcionamento ao mesmo tempo bipolar (de um lado a coisa, do outro a imagem) e em sentido único: da coisa à imagem, do exterior (o mundo) para o interior (a câmara escura)" (2009, p. 76). Talvez seja ainda pelo próprio caráter de indicialidade, no sentido peirciano do termo, que se pode supor nessa imagem, a ideia de vestigium, de traço e presença que se opõe, por sua vez, às artificialidades representacionais do signo.

Os semioticistas peircianos veem nisso simplesmente a presença de algo que é da ordem fundadora do signo indiciário, o traço, o rastro, o contorno, enfim, um oco que determina que em algum momento, ocorreu um contato. Já Barthes parece preencher esse espaço vazio com uma película de matéria viva, talvez mesmo um ínfimo pedaço de pele que, diferentemente do oco indiciário, que simplesmente evoca a existência daquele que ali deixou um rastro do seu corpo, os raios luminosos, que constituem a imagem fotográfica, são a evidência da presença do sujeito representado, nessa querela de luz que dele partiu e se fixou, pela ação química, sobre a película sensível dos sais de prata. Os sais de prata - metal precioso e vivo - acabam a imortalização do ser amado. Lá, onde todos os comentadores de imagem desenham os contornos de um traço (índice) peirciano, isto é, um oco, Barthes deposita uma película de matéria viva, um alívio pleno, ínfimo, um pouco de pele, justamente palpável.

Disso tudo, num golpe de sofisticação, Barthes nota que, para apreendermos seriamente a imagem fotográfica, é necessário pensar numa "ciência dos restos" [science des restes] (sd., f. 37$)^{7}$ que leve em consideração as várias camadas de significação já previstas no substantivo francês "reste": pequena quantidade restante de um todo, o que permanece depois uma destruição, extração; portanto, traços, vestígios, dejetos, cinzas. E o verbo francês rester complementa essa concepção de ciência, pois sua raiz se origina no latim restare, em francês, s'arrêter, imobilizar, bem como être de reste, continuar a ser, manter, permanecer. Esse jogo de palavras nos possibilita pensar na concepção barthesiana de fotografia: alguma coisa do sujeito que se pôs diante da objetiva foi imobilizada [s'est arrêté], e ali permaneceu [est resté] como um vestígio, traço [du reste] daquilo que foi [ça a été], mas que, quimicamente, está ainda aqui [c'est encore là].

Ora, a imagem fotográfica, enquanto emanação físicoquímica do objeto, um rastro de luz, uma chamuscada do real, é sempre um duplo, diríamos mesmo, uma arte moder- 
na de mumificar, pois a imagem que ela nos revela é, de fato, "[...] a diferença e a separação entre o real fotografado - nota Lucia Santaella - que foi engolido pelo tempo que passa, e o seu registro - capturado, congelado e eternizado na foto" (2009, p. 58). A perspectiva barthesiana de leitura da fotografia em A câmara clara mistura, notadamente, a crença e, também, a "ficção química" dessa imagem, o que, ao nosso ver, o faz depreender uma certa esperança numa ressurreição possível, a partir de uma confusão entre o real e o vivo.

Assim, ao lermos as imagens fotográfica como aquilo que resta, o resto daquele sujeito que foi fotografado, estamos num certo sentido, a meio caminho da loucura e da alucinação. Num certo sentido é manter com a fotografia uma relação de fetichismo, ao evocar num mesmo corpo, num mesmo espaço características de mortos-vivos, de orgânico e inorgânico, de animado e inanimado. No entanto, o fetichismo não consiste simplesmente em tomar o que é imaginário por real, mas de tomar o inanimado por animado. E aí, a cópia, o simulacro, toma lugar do objeto concreto. Nota Barthes que "se a fotografia se torna horrível é porque certifica, por assim dizer, que o cadáver está vivo, enquando cadáver: é uma imagem viva de uma coisa morta" (OC, V, p. 853) que nos remete, por sua vez, aos museus de cera, onde a fronteira entre o animado (aquilo que tem alma/vida) e o inanimado se torna tão tênue que não sabemos mais o que é verdadeiro ou simulacro, qual é a cópia ou o real tal é a sua semelhança. Se é do ponto de vista do teatro que a foto toca o campo da arte, essa perspectiva de leitura não irrompe se não a partir de uma relação fetichista como imagem como se ela fosse algo morto-vivo ao mesmo tempo, o que também já nos mostra o teatro em sua origem em que "caracterizar-se era apresentar-se como um corpo simultaneamente vivo e morto" (OC, V, p. 793). A fotografia é essa representação imóvel/pintada que se quer fazer viva uma espécie de "quadro vivo" pelo seu efeito, muitas vezes estupefante -, na qual se revela os mortos.

A fina crítica que faz Barthes em A câmara clara sobre a fotografia acaba por situá-la para além das tradicionais figuras de linguagem: o paradoxo, presença de uma ausência; metonímia, a parte pelo todo; Barthes percebe, diante de certas fotografias além do objeto e de sua representação não se dissociarem, sua representção traz, misticamente, e inesperadamente, no seu bojo, a complitude do ser representado, seu "ar". Noutros termos ainda, a presença do indizível na imagem, a essência daquele que ali se figura. Essa espécie de 
atmosfera que emana do semblante. Uma expressão que estampa que se revela por inteiro, como uma aparição e que, portanto, não pode ser decomposto. Escreve assim Barthes, numa das últimas páginas de A câmara clara, "o ar é está coisa exorbitante que leva do corpo à alma” (OC, V, p. 876). O “ar" é despojado de qualquer significação, é aquilo que transparência quando o sujeito está ali, para além de toda pose.

\section{NOTAS}

1. Valho-me, aqui, da letra mesmo de Roland Barthes, no Avant-propos para edição de 1970 de seu Mitologias em que faz alusão às desmontagens da crítica marxistas, que pecam, - na visão de Barthes -, por serem sem minúcia e, por isso mesmo, piedosas, por não saber comensurá-la à seu objeto. Assim, redige Barthes: "[...] eu acabara de ler Saussure e ficara a convicção de que, tratando as 'representações relativas' como sistema de signos, seria talvez possível sair da denúncia piedosa e revelar em detalhe a mistificação que transforma a cultura pequeno-burguesa em natureza universal" (OC, II, p. 673) [grifo nosso].

2. Arlindo Machado, no ensaio "O quarto iconoclasmo", faz uma espécie de arqueologia da história na tentativa de deflagrar os momentos de "surtos iconoclastas", isto é, manifestações de horror às imagens; alvejando contra as suas ações danosas sobre os seres humanos, Machado observa ainda que para aqueles trabalhos em dívida com o modelo marxista em sua vertente adorniana, como Guy Debord Sociedade do espetáculo (1967) e Jean Baudrillard $O$ sistema dos objetos (1968), as imagens são sempre tomadas como: "diabólicas", "profanes", "imorais", "perversas", até mesmo, "pornográficas". MACHADO, Arlindo. O quarto inconoclasmo: ensaios hereges. Rio de Janeiro: Marca d'Água Livraria e Editora, 2001, p. 21.

3. Esse termo é utilizado, aqui, no sentido estabelecido pela estudiosa das ciências da linguagem, Julia Kristeva, em La révolution du langage poétique. Para a ela, a significância designa algo dessa vaga atmosfera de sentidos em que o ser humano vive imerso ainda no estado embrionário. Os traços desses sentidos são pulsionais e não se encontram ainda articulados como signos. Em outros termos, uma forma de expressão ainda não está amarrada a um significado. Desse tempo de antanho, o sujeito não há nenhuma preservação de significados, apenas uma nostalgia da maneira pela qual pulsões agem nas relações originárias de mediação do corpo com o mundo. Desse ponto de vista, a significância remete à nossa imaginação e nos faz vivenciar a ilusão de resgatar espectro da ordem do imemorável.

Julia Kristeva. La révolution du langage poétique. Paris: Seuil, 1974, p. 25.

4. As referências às obras de Roland Barthes foram retiradas de suas Oeuvres Complètes em V Tomos, organizadas por Éric Marty e editado pela Seuil em 2002. Doravante mencionada sob forma abreviada OC seguido do número em romano do tomo referente.

5. Tempo verbal existente em língua indo-europeia com o grego e o sânscrito que indica uma ação ou um acontecimento, sem que seja definido absolutamente o seu tempo de duração, ou ainda, sem definir com precisão o tempo em que a ação ocorreu.

6. Roland Barthes. La chambre claire. OC, V. Paris: Seuil, 2002, p. 854.

7. Encontramos essa nota em uma das inúmeras fichas da "pochette" intitulada "Sur la photo", que consiste em fichário de notas preparatórias para escrita de A câmara clara. 


\section{Referências}

BARTHES, Roland. Oeuvres Complètes. V tomes. Paris: Seuil, 2002.

. Fonds Roland Barthes [BRT2.]. Grand Fichier. Pochette [ Sur la Photo], Paris: Bibliothèque Nacionale de France.

. La chambre claire [BRT2.A21.01.02.03] Chutes/ premier brouillon. Fonds Roland Barthes. Paris: Bibliothèque Nationale de France [Fragment 9].

BAZIN, André. O que é o cinema. São Paulo: Brasilien, 1991.

CALVET, Louis-Jean. Roland Barthes - uma biografia. São Paulo: Siciliano, 1993.

COMMENT, Bernard. Roland Barthes, vers le neutre. Paris: Christian Bourgois Editeur, 2002.

DUBOIS, Philippe. O ato fotográfico. Campinas: Papirus, 2008.

FRADE, Miguel. Figuras do espanto - a fotografia antes da sua cultura. Porto: Edições Asa, 1992.

GROJNOWISKI, Daniel. Usages de la photographique. Paris: José Corti, 2011.

GUITTARD, Jacqueline. La photographie ou l'épreuve de l'écriture. Thèse de doctorat sous la direction d'Eric Marty. Paris: Université de Paris VII, 2004.

KRISTEVA, Julia. La révolution du langage poétique. Paris: Seuil, 1974.

MERLEAU-PONTY. Mauricie. O visível e o invisível. São Paulo : Perspectiva, 2007.

MOTTA, Leda Tenório da a. Roland Barthes - Uma biografia intelectual. São Paulo: FAPESP/Iluminuras, 2011.

NIÉPCE, Nicéphore. Nicéphore Niépce. Collection Photo Poche. n. 8. Paris: Centre Nacional de la Photographie, 1983. PIERCE, Sander Charles. Écrits sur le signe. Paris : Seuil, 1978. ROUILLÉ, André. A fotografia. Entre documento e arte contemporânea. São Paulo: Senac, 2009.

SANTAELLA, Lucia. Lições $\mathcal{E}$ subversões. São Paulo: Lazuli, 2009.

STIEGLER, Bernard. La technique et le temps 2. La désorientation. Paris : Galilée, 1996.

VAN LIER, Henri. Philosophie de la photographie. Paris-Bruxelles: Les Impressions Nouvelles, 1983.

Recebido em: 24/06/14

Aceito em: 20/o8/14 


\section{RODRIGO FONTANARI}

fontanari.rodrigo@yahoo.fr

Pós-doutorando no Programa de Pós-graduação em Multimeios da Universidade Estadual de Campinas. Doutor pelo Programa de Pósgraduação em Comunicação e Semiótica da Pontifícia Universidade Católica, sob a orientação de Leda Tenório da Motta, de São Paulo. Bolsista da FAPESP com estágio de pesquisa de doutoramento, junto à Université de Paris VII -Denis Diderot, sob orientação de Éric Marty e ao Centre Roland Barthes, dirigido por Julia Kristeva. 